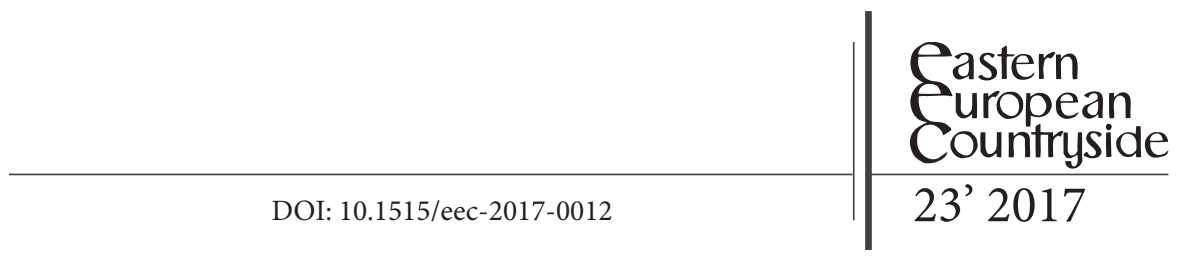

\title{
Krzysztof Gorlach
}

Institute of Sociology, Jagiellonian University, Kraków, Poland

\section{Rural Sociology at the Jagiellonian University in Cracow: Past and Present ${ }^{*}$}

The $27^{\text {th }}$ Congress of the European Society of Rural Sociology (ESRS) will take place on 24-27 July 2017. This year it will be held at the highly hospitable Jagiellonian University, the oldest university in Poland established in 1364. The decision of the ESRS authorities to choose Poland and, specifically, the Royal City of Kraków for this year's Congress is undoubtedly a great honour for the Polish community of rural sociologists, recognised as one of the biggest and most active in Europe. For nearly 100 years, the development of this subdiscipline has been driven by the major contribution of sociologists associated with the centre in Kraków, functioning mainly, albeit not exclusively, within the structures of the Jagiellonian University Institute of Sociology.

The article was written by Professor Krzysztof Gorlach, one of the most prominent contemporary rural sociologists, author of numerous books and scientific articles, published, among others, in Eastern European Countryside (of whose Advisory Council he has been a member since 2013). To mark the organisation of the Congress in Kraków, we have addressed our esteemed colleague, as the current leader of the Kraków group of rural sociologists and Chairman of the Local Organising Committee of the $27^{\text {th }}$ European Congress of Rural Sociology, to write a few words about the history of this subdiscipline at the Jagiellonian University. 
In 1921 the idea to form a chair of ethnology and ethnography has been formed in the context of seeking for a proper candidate. It should be stressed that Bronisław Malinowski (18884 - 1942) has been perceived at that time as one among various potential candidates. However, he did not accept such a proposal because of his plans to analyse important research materials gathered earlier at the Trobriand Islands, as well as some ideas to organise another research trip to this region. As a result, in November 1922, Jan Stanisław Bystron (born in 1894, died in 1964) was invited to become Professor of Ethnology at the Jagiellonian University. However, it was not earlier than in 1925 when Bystron finally became the professor of ethnology and ethnography at the university.

Five years later the chair of ethnology and ethnography was transformed, following Bystron's ideas, into the chair of ethnography and sociology. Therefore, Bystron should be mentioned as a first sociologist working at the Jagiellonian University until 1934 when he moved to Warsaw University. However, he left the chair of ethnography and sociology at the Jagiellonian University in Kraków, which was distinguished among other academic scientific centres in Poland because of its specific area of scientific interests and studies. Such a peculiarity lies in the combination of sociology and ethnography with a singular stress on historical development and some connections to German, French and English traditions in terms of cultural studies.

In this context Kazimierz Dobrowolski (born in 1894, died in 1987) became a new Professor in the Chair of Ethnology and Sociology in 1935. What is important is that Dobrowolski developed not only the ethnological and sociological legacy established by Bystroń, but enriched the analysis with a historical perspective following the ideas of two distinguished historian: Stanisław Krzyżanowski and Franciszek Bujak. Therefore, on the one hand, sociology at the Jagiellonian University has evolved with its strong connection with an ethnographic perspective, while on the other hand, it has taken up a historical dimension. 
World War II disrupted the functioning of the Chair of Ethnography as well as all the activities of the Jagiellonian University. However, already in 1945 (the end of the War) Kazimierz Dobrowolski started to renew the processes of teaching and conducting research in ethnography and sociology. He immediately met with major difficulties since, under the Stalinist ideology dominating in Poland from late 1940s until mid-1950s, sociology was recognised as so-called "bourgeois science". The situation of ethnography had been a little better at that time since it had been recognised in a more "neutral" way, i.e. as a discipline focused mainly on traditional rural cultural patterns. However, as a result of de-Stalinization sociology after 1956 became once again a part of the university curriculum under the frame of Chair of General Ethnography and Sociology headed by Kazimierz Dobrowolski. Moreover, Dobrowolski organised the separate scientific unit; namely, the Chair of Sociology (again) and Demography headed by professor Paweł Rybicki. Both chairs became the backgrounds of the Institute of Sociology at the Jagiellonian University that has been established in $1970^{1}$.

Basing on the ethnographic tradition rural studies became an important part of the research activities performed by persons working at the Institute of Sociology. One should notably mention some works by Kazimierz Dobrowolski that has been focused on the role of peasant culture in historical processes of change in Polish society ${ }^{2}$. The main theoretical message resulting from Dobrowolski's considerations seems to lie in the assumption that to describe and understand the processes of social change we should take into considerations of all the dimensions of social life. Such a perspective has been called an "integral method" and has been formed as a crucial point of reference for rural studies in Poland (not only in Krakow and at the Jagiellonian University).

1 Kwaśniewicz, Władysław (ed) 1989 Uniwersytecki ośrodek socjologiczny w Krakowie. Tradycja i współczesność (Sociological University Center in Kraków. Traditions and Present Times), Warszawa - Kraków: Państwowe Wydawnictwo Naukowe

2 Dobrowolski, Kazimierz 1973 Studia nad życiem społecznym i kulturą (Studies on Social Life and Culture), Wrocław: Ossolineum;

Dobrowolski, Kazimierz 1973 Teoria procesów żywiołowych w zarysie (Theory Od Spontaneous Processes in Brief), Wrocław: Ossolineum 
Władysław Kwaśniewicz (born in 1926, died in 2004) has been a person who continued Dobrowolski's legacy. Therefore, he has conducted some research focused on the role of craftsmen in a peculiar rural community ${ }^{3}$. Such an analysis has demonstrated the role of mixed economic activities in rural communities. Moreover, in the early 1970s, Władysław Kwaśniewicz organised the team of researchers dealing with crucial issues of rural communities. In this team, Lucjan Kocik (born in 1944), Zygmunt Seręga (born in 1947, died in 2014) and Krzysztof Gorlach (born in 1954) should be mentioned. All of them conducted their research focused on rural issues. Lucjan Kocik did his research in the 1970s and 1980s and tried to explain the role of family in major changes of farming communities ${ }^{4}$.

In turn, Zygmunt Seręga conducted his research from the mid-1970s until the mid-1990s. Seręga's initiatives focused on rural communities, including the role of tourism (as a major factor of change in rural communities), as well as the presence of some local institutions (cooperative banks, local authorities and local economic organisations) in the process of rural community changes 5 . The last one has been an attempt to show the role of local institutional arrangements in major processes of rural community changes from the communist-type institutional framework to a more flexible democratic regime resulting from the political breakthrough of 1989. Seręga's studies on rural communities have been continued by Piotr Nowak who conducted research on the role of local elites in processes of rural development. His current study conducted with the financial support of the Ministry of Science and Higher Education has focused on the role of local

3 Kwaśniewicz, Władysław 1970 Wiejska społeczność rzemieślnicza w procesie przemian. Studium socjologiczne wsi Świątniki Górne pow. Krakowskiego (1850-1960) (Craftsmen Rural Community in the Processes of Change: Study on Świątniki Górne in the Kraków County (1850-1960)), Wrocław: Ossolineum

4 See: Kocik, Lucjan 1976 Przeobrażenia współczesnej rodziny wiejskiej (Changes of Contemporary Rural Family), Kraków: Ossolineum;

also: Kocik, Lucjan 1986 Rodzina chłopska w procesie modernizowania się wsi polskiej (Peasant Family in the Proces sof Modernization of Rural Poland), Kraków: Wydawnictwo Uniwersytetu Jagiellońskiego

5 Seręga, Zygmunt 1993 Czynniki rozwoju lokalnego (Factors of Local Development), Kraków: Wydawnictwo Uniwersytetu Jagiellońskiego 
entrepreneurs, representatives of local intelligentsia, leading farmers, etc. in the processes of local development in several selected rural communities ${ }^{6}$.

Starting in the early 1990s, Krzysztof Gorlach has tried to continue research traditions developed by Kwaśniewicz and Kocik with collaboration of Seręga and later with Piotr Nowak (born in 1967) and Grzegorz Foryś (born in 1974). Therefore, his first research initiatives have been focused on the concept of peasantry presented in the context of rural studies developed by Polish sociologists ${ }^{7}$. Later, however, his studies have been expanded into several areas of analysis.

First of all, the analysis of significance of family farming in the context of Polish agriculture should be mentioned ${ }^{8}$. In this study, based on the results of research conducted in the Małopolska region (southern part of Poland with the prevailing number of small family farms), some issues of defending farms as well as developing of various identities should be stressed. Secondly, Krzysztof Gorlach and Zygmunt Seręga have tried to broaden this area of interest - namely, family farming - into an international field. Therefore, they have been the editors of the important volume9.

This perspective was also enlarged in the international context following the international conference held in Krakow in late May 1995. It contained fourteen chapters concerning family farming issues in countries (beside Poland) such as the Netherlands, the United Kingdom, Bulgaria, Russia, the United States and Portugal. This period of the development of studies

6 Nowak, Piotr 2012 Rozwój obszarów wiejskich w Polsce po integracji z Unia Europejską w opinii lokalnych elit (The rural areas development after European integration in the local leaders opinion), Kraków: Wydawnictwo Uniwersytetu Jagiellońskiego.

7 Gorlach, Krzysztof 1990 Socjologia polska wobec kwestii chłopskiej (Peasant Question in Polish Sociology), Kraków: Universitas

8 Gorlach, Krzysztof \& Seręga, Zygmunt 1991 Chłopi we współczesnej Polsce: podmiot czy przedmiot procesów społecznych (Peasants in Contemporary Poland: Makers or Outsideders of Social Processes), Kraków - Warszawa: Polskie Wydawnictwo Naukowe

9 Gorlach, Krzysztof \& Seręga, Zygmunt (eds) 1995 Family Farming in the Contemporary World: East-West Comparisons, Kraków: Jagiellonian University Press 
on family farming issues has been supplemented with two important studies focused exclusively on the issues facing family farms in the United States.

We have in mind here two volumes prepared by Lucjan Kocik as well as Krzysztof Gorlach. The first one has focused on farms operated by Polish origin farmers in the Mid-West region ${ }^{10}$. The second one has been developed as a kind of historical-sociological study focused on the history of family farming in the United States ${ }^{11}$. In the last case, the author claims that the family farm might be perceived as one of the most important icons in the American history, while its development might be treated as a kind of struggle of the American tradition against the forces of industrialisation and globalisation shaping the conditions of the American economy and society.

Major changes in Poland after 1989 have brought some new themes and issues elaborated by rural sociologists at the Jagiellonian University. The first one was prepared by Zygmunt Seręga in his analysis of the conditions shaping some ways of local rural development. Basing on the mostly qualitative research in several mountain area communities in southern Poland, the author claimed the vital role of local institutions and local elites in the processes under his considerations. Such a study was continued about twenty years later by Piotr Nowak in his analysis of local development, stressing the roles of local elites as well as EU projects.

The consideration of Polish peasants (farmers) as an important social category became a topic of three consecutive studies conducted by Krzysztof Gorlach in the years 1994, 1999, 2007 ${ }^{12}$. The main analysis in these publications cover some fundamental changes occurring in rural Poland under the processes of post-communist transformation, including the issues

10 Kocik, Lucjan 1990 Polski farmer w Ameryce: Studium przypadku stanu Wisconsin w USA (Polish Farmer in America: The Case Study of Wisconsin), Kraków: Ossolineum

11 Gorlach, Krzysztof 1994 Obronić ducha Ameryki: kwestia rolna i socjologia wsi we współczesnych Stanach Zjednoczonych (Defending the Spirit of Rural America: Agrarian Question and Rural Sociology in the United States), Kraków: Wydawnictwo Uniwersytetu Jagiellońskiego

12 Gorlach, Krzysztof 1995 Chłopi, rolnicy, przedsiębiorcy: „kłopotliwa klasa” w postkomunistycznej Polsce (Peasants, Farmers, Entrepreneurs: the „Awkward Class” in Postcommunist Poland), Kraków: Kwadrat -Wydawnictwo Uniwersytetu Jagiellońskiego; Gorlach, Krzysztof 2001 Świat na progu domu: Polskie rodzinne gospodarstwa rolne w obliczu globalizacji (The World in my Backyard: Polish Family Farms in the Face of Globalization), Kraków: Wydawnictwo Uniwersytetu Jagiellońskiego; 
of economic and cultural capital of investigated farms, the types of identities observed among farm operators, the types of class consciousness in the farming community and ways of defending farmers ' interests.

This research had the character of a panel study enabling to follow the trajectories of farms between 1994 and 2007, i.e. in the key period of Poland's preparing and entering the European Union. Additional aspects of the analysis of these processes have been developed by Lucjan Kocik in his book about traumatic experiences and Eurosceptical tendencies observed among rural population in Poland in the process of major economic and social changes ${ }^{13}$. Moreover, Krzysztof Gorlach, Zygmunt Seręga and Zbigniew Drąg have prepared a similar investigation focused on the young rural generation in Poland and their attitudes towards the idea of European integration ${ }^{14}$.

Another important characteristic of scientific activities undertaken by rural sociologists at the Jagiellonian University might be the so-called political sociology of agriculture. It has focused especially on farmers ' protests in Poland, treating them as a way of defending their interests while, at the same time, as a way of constructing new regime in the areas of agricultural and rural policies.

Krzysztof Gorlach and later Grzegorz Foryś have conducted some research focused on protests of Polish farmers after 1989 trying to follow this particular issue. The results of this type of analysis have been presented in different social and cultural as well as political contexts. First of all, they have been presented as a separate analysis of farmers ' protests in Poland due to existing theoretical framework of social protests and social movements ${ }^{15}$. Secondly, they have been analysed as a part of a more international discourse

Gorlach, Krzysztof 2009 W poszukiwaniu równowagi: Polskie rodzinne gospodarstwa rolne w Unii Europejskiej (Searching for the Balance: Polish Family Farms in European Union), Kraków: Wydawnictwo Uniwersytetu Jagiellońskiego

13 Kocik, Lucjan 2001 Trauma i eurosceptycyzm polskiej wsi (Trauma and Euroscepticism in Rural Poland), Kraków: Universitas

14 Gorlach, Krzysztof; Seręga, Zygmunt \& Drąg, Zbigniew 2003 Młode pokolenie wsi Trzeciej Rzeczpospolitej (Young Rural Generation of the Third Republic of Poland), Warszawa: Instytut Spraw Publicznych

15 Gorlach, Krzysztof \& Foryś, Grzegorz 2002 'The Dynamics of Polish Peasant Protests under Postcommunism', Eastern European Countryside 8: 47-66 Foryś, Grzegorz 2008 Dynamika sporu: Protesty rolników w III Rzeczpospolitej (The Dynamics of Contention: Farmers ' Protests in the Third Republic of Poland), Warszawa: Scholar 
concerning the issues of democratisation in formerly authoritarian regimes observed in Latin America, South Africa as well as East-Central Europe ${ }^{16}$.

Rural sociologists at the Jagiellonian University have also been involved in various international projects. In starting to present this issue, we should mention the CORASON project as part of European Union $6^{\text {th }}$ Frame Programme focused on the role of types of knowledge in the processes of rural development. This initiative was undertaken in the years 2004-2007 and resulted in several publications both in English and Polish concerning food regional products, natural resource management and the role of various types of knowledge in rural development, etc ${ }^{17}$.

Moreover, this type of research has been extended to the multidimensional analysis of important roles of regional food products in the context of rural development ${ }^{18}$. The issue of agri-tourism has been perceived as an alternative type of economic activities performed by farmers and other inhabitants in rural areas. It has been an object of extensive research conducted by Grzegorz Foryś. The main message of this research has been focused on the emergence of a peculiar social movement in rural areas focused on agritourist offers and activities $^{19}$.

16 Foryś, Grzegorz \& Gorlach, Krzysztof 2015 'Defending Interests: Polish Farmers ' Protests under Postcommunism' in: Bert Klandermans, Cornelius van Stralen (eds) Movements in Limes of Democratic Transition, Philadelphia - Rome - Tokio: Temple University Press, pp. 316-340

17 Gorlach, Krzysztof; Adamski, Tomasz \& Klekotko, Marta 2009 'Designing Nature and Resource Management Strategies' in: Karl Bruckmeier \& Hilary Tovey (eds) Rural Sustainable Development in the Knowledge Society, Farham: Ashgate, pp. 187-202;

Adamski, Tomasz \& Gorlach, Krzysztof 2010 'One Tradition Many Recepies: Social Networks and Local Food Production - the Oscypek Cheese Case' in: Maria Fonte \& Apostolo G. Papadopoulos (eds) Naming Food after Places: Food Relocation and Knowledge Dynamics in Rural Development, Aldershot: Ashgate, pp. 173-196; Gorlach, Krzysztof et al. 2007 Wiedza w zrównoważonym rozwoju obszarów wiejskich (Knowledge in Rural Sustainable Development), Kraków: Wydawnictwo Uniwersytetu Jagiellońskiego

18 Gorlach, Krzysztof et al. 2016 'Local Food as an Agent of Regional Rural Development: Three examples from the Małopolska Region in Poland', Socio.hu, Space and Society: Special Issue in English 4: 160176 (Available : http://www.socio.hu/uploads/ files/2016en/gorlach.pdf)

19 Foryś, Grzegorz 2016 Gospodarstwa i stowarzyszenia agroturystyczne w Polsce. W poszukiwaniu ruchu społecznego (Agrotourist Farms and Associations. Searching for a Social Movement), Warszawa: Scholar 
Moreover, it should be stressed that the issues of natural environment and its role in the processes of rural change in Poland have had a significant tradition among rural sociologists at the Jagiellonian University. In this context, one might mention the work by Lucjan Kocik focused, on the one side, on some relations between farms and society as well as their relations with nature on the other ${ }^{20}$.

Following this pattern of scientific activity, the team of rural sociologists at the Jagiellonian University has been involved in the recent international research project under the HORIZON2020 EU program. The project under the SUFISA acronym has focused on the analysis of sustainable financing for sustainable agriculture and fisheries. Major research interest has been focused on the conditions, strategies and performances of farmers in different sectors and various countries. The completion of the project has been planned in April 2019. The project gathers thirteen academic institutions from eleven countries (Belgium, UK, Italy, France, Portugal, Greece, Latvia, Germany, Serbia, Denmark and Poland).

More recently, a major project concerning key changes in farming community in Poland has started with the support of National Science Center under the MAESTRO program. The project headed by Krzysztof Gorlach started in April 2016 and had been planned for 5 years. The title of the whole project is: "Think Locally Act Globally: Polish Farmers in the Era of Globalisation and Resilience" (UMO-2015/18/A/HS6/00114, el. PSP K/ $\mathrm{PBN} / 000032)$. The main idea of the project has been based on the reversion of the famous and well-known statement "Think Globally, Act Locally". We argue that farmers construct their business strategies by thinking about local conditions and the contexts of farming to act beyond the local to mobilise various resources to achieve success in their businesses.

The idea of the project is to analyse these strategies and their diversification across the whole country in various regions and sub-regions using multi-level analysis applied to a huge national sample containing at least 3000 units (farms). Moreover, some qualitative analysis is to be conducted based on in-depth interviews with some selected respondents (farmers and

20 Kocik, Lucjan 2000 Między przyrodą, zagrodą i społeczeństwem. Społecznokulturowe problemy ekologii wsi i rolnictwa (Between Nature, Farm and Society. Sociocultural problems of rural and agricultural ecology), Kraków: Wydawnictwo Uniwersytetu Jagiellońskiego 
representatives of agricultural chambers) concerning the issues of life style, class identity, food safety and security, using information technologies as well as exploring ways of defending farmers' group interests.

The research team headed by Krzysztof Gorlach contains a few other members, namely: Dr. Zbigniew Drąg (hired as a database manager), Martyna Wierzba-Kubat, M.A. (hired as a research assistant, working in collaboration with Piotr Nowak) who is responsible for analysis of food safety and security and information technologies issues and Dr. Adam Mielczarek (hired as a post-doc) who is responsible for analysis of class and life style issues. Moreover, the research team has been supported by two foreign experts called "external theorising evaluators"; namely, Jan Douwe van der Ploeg (Wageningen University, the Netherlands) and Patrick H. Mooney (University of Kentucky, Lexington, USA). 